\title{
ALL THE WORLD IS A SCREEN: THE POWER OF MEDIA SIMULACRA IN THE NOVELS OF DON DELILLO
}

ABSTRACT :

\begin{abstract}
This essay discusses the extent and effects of media simulacra on the fictional world of the North-American novelist, Don Delillo, during the three decades of his work. The study relates media simulacra in the novels to the theory of simulacrum developed by the French theorist Jean Baudrillard.
\end{abstract}

KEY WORDS: Don DeLillo, Jean Baudrillard, media simulacra.

Recently, in the North-American television program, 60 Minutes, a teenageboy involved in one of those dire massacres in high schools was asked about his greatest fear. He was sentenced to two hundred years of prison, and he could only be released under probation at the age of seventy-five. His greatest fear, though, was that other crimes would become media headlines, and his feats would no longer be remembered by the media.

The 60 Minutes program illustrates what the novelist Don DeLillo has been portraying in his novels, a fictional urban society in which the characters are deeply and constantly influenced by the media in their daily lives. Delillo's novels show that television, being the most popular communication medium in North-America, has turned life into two categories, the ordinary and the televised, "...television becomes the dominant technology that changes our relation to the natural world. We experience in its terms, begin to live in reference to it, and ratify experiences in terms of its on-screen simulation" (Tichi, 1992: 152). Thus, what the characters in DeLillo's novels describe as reality, for instance, is mingled with TV shows'

* Mestre em Letras: Estudos Literários (Área de concentração: Literaturas de Expressão Inglesa), 2001. 


\section{EMTESE}

Belo Horizonte, v. 6, p. I-253, ago. 2003

lines and commercial jargon. They are also fascinated with the possibility of "zapping" through the world without leaving their couches, or copying a model of behavior established by television programs.

Society in DeLi1lo's novels is so embedded in the media simulacrum that it is often not possible to know whether the characters are behaving according to media codes or whether they still keep some control of their lives in terms of consumerism and assertion of their bourgeois selves in society. In the novels, especially in those written in the Eighties, the boundaries between media simulacra and reality become blurred.

In América (1986), Jean Baudrillard posits that in hyperreal NorthAmerica, places and experiences are mediated by codes of American ideology; thus, some American landmarks and institutions, such as freeways, motels, Disneyland, and movies, are mediated by American myths of freedom, efficiency and fun. ${ }^{1}$ The replacement of reality by its media simulations, which support American ideology, is a recurring theme in Don DeLi11o's novels. Since Americana (1971), his first novel, Deli110 has been portraying in his writings an urban society in which the characters are constantly influenced by the media in their daily lives, and either pursue, or strive to escape, a media standard of living based on consumerism and the frenetic update of news events. This media environment gives rise to broader conflicts, such as the commodification of the public image of some characters through its reproductions in communication media, the overwhelming of the individual self by mass culture, or the implosion of simulation and reality in the hyperreal media realm.

This article briefly analyses thirty years of development in DeLi1lo's work, organizing the novels into three major groups, each related to the decade in which they were written. In the seventies novels, media simulacra are closely connected to consumerism. DeLi110 conveys the idea that there is no exit from the logic of commodity exchange in the capitalist market, and even the characters are commodified and consumed by the masses of TV viewers.

In the eighties novels, television reigns supreme, and commands the mutation of reality into hyperreality. DeLillo portrays hyperreal environments in which media simulacra have been gradually replacing reality with their codes and 
media technology. Therefore, the characters are always pursuing publicity or engaging in consumerism as a means of achieving happiness and freedom, promised by the media and their sponsoring products.

Celebrity, once achieved by deeds, is now reduced to one's single exposure in the media. This hyperreal realm is what offers authenticity to the facts and events of the world; if someone is on the TV screen worldwide, this person becomes famous, and images are taken for granted. And history, once considered a linear strand of facts, is now put into doubt, deprived of its status of grand narrative, and mingled with other fictional narratives in the realm of the media. This supremacy of images and the characters' distrust of linear historical narrative in the eighties novels in accordance with Fredric Jameson's theory of what he calls "the crisis in historicity" (1997:25). According to Jameson, postmodern subjects live in a schizophrenic period, since they have lost the capacity of organizing themselves in coherent experiences of past, present and future. Therefore, linear history becomes an unattainable narrative, condemning the postmodern subject to seek it through "pop images and simulacra of that history" (1997:25).

In the nineties novels, DeLillo continues to develop the theme of "the crisis in historicity". Historical narrative and texts give way to the media narrative of images, and the individual self, once able to change society and history with its deeds, is replaced by media spectacles and masses of TV viewers seeking entertainment. As soon as the media take hold of events, reality is replaced by its simulacra, with swarms of journalists and cameras, and masses of TV viewers watching the events. It is a time of overexposure to the cameras, and the suppression of the individual in the name of collective entertainment. Media celebrity replaces Benjamin's aura (1982) in the realm of hyperreality. There is not such a thing as uniqueness; images are endlessly reproduced, signs are constantly associated among them, and the aura of objects gives way to fame.

Throughout these three decades, its possible to notice how DeLi1lo's novels have evolved from a criticism of the capitalist logic of commodity exchange to a criticism of a society embedded in media simulacra, or, to use a term coined by Jean Baudrillard, a society based on the fourth order of simulacra. 


\section{EMTESE}

Belo Horizonte, v. 6, p. I-253, ago. 2003

To understand Baudrillard's fouth order of simulacra, it is necessary to have a look at his early writings. Baudrillard's early career is strongly influenced by Marxism. His second order of simulacra, for instance, is based on the capitalist logic of use/exchange-value of a commodity. According to Baudrillard the use-value of a commodity, or its purpose of satisfying needs, can be paralleled with the signifier of the sign, with the signified being the needs to be satisfied. The exchange value of a commodity would be then the contrast of this commodity (sign) with other signs in the market (Baudrillard, 1996). However, in postmodern societies, that difference among signs is not grounded in reality. Signs are manipulated, so that the differences are made by the affiliation of certain signs with abstract models. That is, commodities acquire certain features based on prestige, style, power, and so on, which are called their sign-values, a more important constituent of the commodity than its use-value and exchange-value, and a determinant of its consumption. Baudrillard believes that, "you never consume the object in itself [...] you are always manipulating objects [...] as signs which distinguish you either by affiliating you to your own group taken as an ideal reference or by marking you off from your group by reference to a group of higher status" (Baudri1lard, 1988: 61).

Having deviated from Marxism, Baudrillard borrowed Barthes' study of signs to devise a new regimen of sign-value for commodities in contemporary society. Signs are manipulated through a metonymic relation, in which prestige or some other abstract model is added to a commodity by its association with other signs in society, e.g., a sports car is associated with a certain type of life-style and people, and finally with the consumer, who identifies himself in this chain of signassociations. The system of sign-value in society produces a parallel improvement in advertising, fashion, consumption, and mass communication media. This new reality of the media and self-referential signs is what Baudrillard describes in the fourth order simulacra, in which simulation models overtake and replace representation in order to constitute an autonomous realm in contemporary 1 ife-a realm of hyperreality.

One can perceive in Baudrillard's theory of simulacra the influence of the media theory of the Canadian critic Marshall McLuhan, who analyses, in Understanding Media (1965), the media environment, and privileges the form of media technology 
over its content with his famous statement that "the medium is the message". For McLuhan, communication and its content are neutralized by the masses's fascination with the medium itself. The message is not so important as the social and individual changes produced in the masses by their relation to television.

Following Marshal1 McLuhan, Baudrillard argues that

the true message the media of TV and radio deliver, the one which is decoded and consumed deep down and unconsciously, is not the manifest content of sounds and images, but the constraining pattern- linked to the very technical essence of those media- of the disarticulation of the real into successive and equivalent signs [...]. It is their function to neutralize the lived, unique, eventual character of the world and substitute for it a multiple universe of media [...]. What TV medium conveys by its technical organization is the idea of a world endlessly visualizable, endlessly segmented and readable in images (Baudrillard, 1998: 122-123).

Therefore, the media, believed to mirror or reflect reality, are interpreted by Baudrillard as themselves a new reality: hyperreality, whose images, signs and codes, simulate an autonomous realm in everyday life. He also uses the concept of implosion to explain that in the fourth order simulacra, the limits between media simulations and reality implode, and the result is that the experiences grounded exclusively on the real have been disappearing.

One can notice that the theory of simulacra developed by Jean Baudrillard can be connected with DeLillo's novels' plots. In order to understant such thematic and theoretical proximity, I will briefly introduce his work. In Americana (1971), DeLillo's first novel, the character David Bell, for instance, illustrates how hyperreality has been gradually replacing reality, when he behaves according to media codes, copying from Burt Lancaster and Kirk Douglas a personal style that is considered the personification of success in America, confusing the scenes he has seen in the films with his own reality. Although Bell strives to find in the west a different American society, without the capitalist values of the East, he realizes in the end that there is no escape from the rules of commodity exchange of the capitalist market. Media hyperreality has also replaced the "wild west" America, bringing with it consumerism and patterns of behavior that are aimed at reiforcing the American myth of an abundant consumer society that offers equal opportunities for those who are ready to plunge into its market and work hard. 


\section{EMTESE}

Belo Horizonte, v. 6, p. I-253, ago. 2003

A recurring theme in Don DeLi110's novels is the fact of someone being turned into a celebrity by being exposed to media simulacra. In Great Jones Street (1973), Deli110's third novel, he shows how overexposure in the media affects the main character, Bucky Wunderlick, a rock star who steps out of a tour to hide himself in a flat in New York. The novel shows that because Bucky's images are reproduced in the media and consumed by his fans, the cult of his persona rises. Media hyperreality has overtaken the world of Great Jones Street, leaving Bucky with no possibility of restarting his career without being turned into an image, endlessly reproduced in the realm of media hyperreality, and endlessly commodified in the phonographic market. Furthermore, the reproducibility of his records reinforces the popularity of his persona in such a way that, instead of finding a realm of reality without media simulacra in his seclusion, he ends up as a legend of rock and roll promoted by the media.

The postmodern environment, in which Baudrillard develops his theory of media simulacra, is the main subject in Players (1977), since the terrorist plot in the novel, as well as the characters involved in it, are not so important to the story as its setting. DeLillo's players move through the movies, motels, financial districts, living rooms and TV sets, as postmodern culture and its symbols are outlined to the readers. A parallel can be drawn between David Be11, in Americana (1971), and the main couple in Players, as these characters perceive the world around them by means of media simulacra. The once active couple are now "couch potatoes", who rely on television images to entertain them and offer a safe view of the world without their need to engage in any type of real activity. Not only does television mediate the real world and the characters, it also mediates their relationship, since they watch TV in separate rooms, and shout at each other over the programs they are watching. It is worth noticing that the characters are not so interested in the content of the programs as they are in manipulating the appliance. The acts of sitting in front of the TV set, turning it on, and "surfing" the channels become more important to them than the content of the news and shows. It means that DeLillo is also concerned about the changes television has caused in society and in family structures, and he warns that information and its content give way to images and TV "zapping". 
In Running Dog (1978), the last novel written in the seventies, Deli1lo continues to develop the theme of generating one's famous persona by media simulacra, introduced in Great Jones Street (1973). In Running Dog as well, everything is commodified, from films to pieces of pornographic art. Like the drug and Bucky's songs in Great Jones Street (1973), the Nazi film is the most desirable commodity in the novel, being pursued by different segments of society, including the mafia and the government.

The Names (1982) is the first novel written in the eighties, and even though language is its main subject, DeLillo also shows his concern about the important role the media play in the characters's lives. To be considered worth noticing, the events in the novel have to be captured by the lenses of a camera. An Irishman from the IMF (International Monetary Fund), for instance, fears going undocumented in city after city, and being killed by a terrorist act that will not be covered by the media. In the Names, the authenticity of a fact is guaranteed by the media news.

In White Noise (1985), media simulacra have overtaken reality, constituting a realm of hyperreality on which the everyday lives of the characters are grounded. In the city of Blacksmith, there are no more experiences based exclusively on reality. Even a toxic accident has its effects controlled by the media reports. The size, shape and side effects of the accident are modified right after the media, which also include the radio in this novel, announce their reports. Not only are events manipulated by the media reports, but also the characters' response to the media spectacle, as the children begin to feel all the side effects of the toxic cloud described on the radio only after they are broadcast.

The perfect images broadcast on television dispense with reality and replace it with media simulacra of reality: hyperreality (Melo, 1988). However, the content of these images is neglected by the characters, who are fascinated with the possibility of "zapping" through the world without leaving their couches. Information floats from side to side but cannot be retained by the characters, since its importance is undermined by the images created by media spectacles around events. One of the characters even strives to match the words as they are spoken, even though she only remembers, while she is sleeping, the name of Japanese car makes. 


\section{EMTESE}

Belo Horizonte, v. 6, p. I-253, ago. 2003

This scene illustrates how consumerism has entered into the characters most private thoughts and dreams. To consume, in White Noise, is to find happiness and freedom; consumerism has become the myth of satisfaction of the characters's needs. And such an urge to consume is created by the media, which means that media simulacra reinforce the logic of commodity exchange and commodities' sign-value in the capitalist market, a recurring theme also found in Americana (1971).

DeLi1lo's ninth novel, Libra (1988), is about the life of Lee Oswald, the character whose behavior is grounded on media hyperreality, insofar as his actions follow media codes of TV shows and films. Throughout the novel he incorporates American myths conveyed by the media, as the US marine or the cowboy, leading a life in which the boundaries between simulation and reality no longer exist. As William Cain asserts, "Oswald does not perceive the movies as fiction or fantasy, but as another, maybe primary dimension of reality..." (1990: 284). When 0swald meets John Wayne, for instance, he is impressed by the fact that the actor, in real life, behaves like his image in the movies, "he watches John Wayne talk and laugh. It's remarkable and startling to see the screen laugh repeated in life. It makes him feel good" (93).

To counterpose Lee Oswald's image, DeLi110 portrays the American president John Kennedy, as if the characters were the opposing pans in a scale. Both characters are dyslexic and driven by the media-what they cannot express through words, they convey by means of their images. Kennedy's life shows how reality is easily simulated in the realm of the media, and how the images displayed on TV screens do not necessarily correspond to reality. However, because television has always shown images of the world as if it were merely mirroring them, instead of mediating them to viewers by means of cameras and editing techniques, what is shown on television is accepted as reality by the viewers. Inasmuch as those images are emptied of any content, they can be easily manipulated for whatever aims the networks desire, so that the audiences can consume Kennedy's images with the belief that he is what the media show him to be.

DeLi1lo conveys in Mao II (1991), the idea that it is exactly through media simulacra that the cult of the one's persona is born, an effect already 
depicted two decades before, in Bucky Wunderlick's image and songs in Great Jones Street (1973), and Hitler's image in Running Dog (1978).

Mao II deals with the conflicts of a humanist writer in a society of media simulacra, showing that his beliefs do not stand a chance in a world where images undermine words. The writer Bill Gray cannot understand that writers are not able to shape people's consciousness any more; this is now the role of the media, and because of that, he is unable to finish his last book. The terrorists in the novel are those who understand that mass communication media keep seeking an audience in order to attract producers, and the old formula for success involves catastrophes, crimes, and a large number of programs which not only fail to stimulate the receiver's intellect but also mesmerize him with catchy headlines, easy-listening songs, and short-time programs. Opposing Bill Gray, they also understand there is no escape from media hyperreality; since events interest the media, reality is replaced by the media circus of TV cameras and journalist competing for the highest audiences. As Haddad, the terrorists' spokesman, says to Bi11 Gray, "everything else is absorbed. The artist is absorbed, the madman in the street is absorbed and processed and incorporated. Give him a dollar, put him in a TV commercial..." (157). Even Bill Gray is absorbed, his manuscripts are passive commodities of the author's royalties, and, in spite of his being a recluse, the fame of his persona is reinforced in the media because of the reproduction of his novels, the same phenomenon experienced by the rock star, Bucky Wunderlick, with his image and songs, in Great Jones Street (1973).

Although media simulacra are not its main subject, Underworld (1997) still maintains some traits that enable this novel to be included in the theme of the connection between media simulacra and DeLi110's fictional characters. Furthermore, it is also Deli1lo's last novel, and in certain ways can be regarded as a summary of the previous theme discussed so far.

The myth of a wealthy society, in which its citizens' needs are satisfied by consumerism, is also present in Underworld. Yet, since this novel can be regarded as a summary of the previous ones, the reader is confronted with the byproduct of consumerism. Garbage of all types is the post Cold War problem to be solved by the 


\section{EMTESE}

Belo Horizonte, v. 6, p. I-253, ago. 2003

Americans, as well as the Russians. Amounts of garbage keep increasing in the novel, as the characters keep consuming and disposing of their goods. The final message conveyed by DeLi1lo is that happiness and freedom, promised by advertisements, end up in garbage dumpsters.

Throughout these three decades, one cannot fail to notice that the novels depict how television and TV zapping have changed people's relation to the world around them. The possibility of watching the whole world and zapping its images through one's eyes has turned much of society into one of passivity, attracted to images and media values like wealth and celebrity, but careless about the programs's contents and messages. DeLi1lo has noted this change in society, and has been describing in his novels the transition of reality to media hyperreality. His hyperreal societies can be compared with any American city where media hyperreality reinforces consumerism and the capitalist market, and the idea of the US as an achieved utopia, the place of ideal perfection that has already come true on television programs and in films broadcast worldwide.

NOTE:

1. The term "myth" is used here in the sense proposed by Roland Barthes in Mythologies (1970). According to Barthes, the myth today is a sign associated with its connotation in order to generate meaning; in other words, the myth can be considered as a powerful discourse embedded in ideology.

RESUMO:

Este texto discute a relação da teoria do simulacro, desenvolvida por Jean Baudrillard, com a mídia e com a sociedade ficcional descrita pelo romancista norte-americano, Don Delillo, no período de três décadas em que ele vem desenvolvendo sua ficção.

PALAVRAS-CHAVE: Don Delillo, Jean Baudrillard, simulacro da mídia. 


\section{REFERENCES}

BARTHES, Roland. Mythologies. Paris: Seuil, 1970.

BAUDRIALLARD, Jean. A Troca Simbólica e a Morte. São Paulo: Edições Loyola, 1996.

- América. Rio de Janeiro: Rocco, 1986.

Gạịée, 1981

- The Consumer Society: Myths and Structures. London: Sage Publications, 1998.

BENJAMIN, Walter. A Obra de Arte na Época de sua Reprodutibilidade Técnica. In: LIMA, Luiz da Costa (ed). Teoria da Cultura de Massa. 3 ed. Rio de Janeiro: Terra e Paz, 1982. 210-240.

DELILL0, Don. Americana. 1971. New York: Penguin, 1989. $\overline{1989}$. - Great Jones Street. 1973. New York: Vintage, - Libra. New York: Penguin, 1988.

- Mao II. New York: Penguin, 1991.

- Players. 1977. New York: Vintage, 1979.

- Running Dog. New York: Alfred A. Knopf, 1978.

- The Names. 1982. New York: Vintage Books,1989. $\overline{1997 .}$ . Underworld. New York: Scribner Paperback Fiction,

- White Noise. New York: Penguin, 1985.

JAMESON, Fredric. Postmodernism, or the Cultural Logic of Late Capitalism. 7 ed. Durham: Duke University Press, 1997.

KELLNER, Douglas. Jean Baudrillard; from Marxism to Postmodernism and beyond. Standford: Standford University Press, 1989.

MCLUHAN, Marsha11. Understanding Media. New York: McGraw Hi11, 1964.

MEL0, Hygina Bruzzi de. A Cultura do Simulacro; filosofia e modernidade em Jean Baudrillard. São Paulo: Loyola, 1988 .

SCHILLER, Herbert I. O Império Norte-Americano das Comunicações. Petrópolis: Vozes, 1976.

TICHI, Cecilia. Eletronic Hearth; creating an American television culture. Oxford and New York: 0xford University Press, 1992. 